Article

\title{
Functions of Landscape in Games-A Theoretical Approach with Case Examples
}

\author{
Olaf Kühne ${ }^{1}$, Corinna Jenal ${ }^{1, *}$ and Dennis Edler ${ }^{2}$ \\ 1 Department of Geosciences, Eberhard Karls University Tübingen, Urban and Regional Development, \\ Rümelinstraße 19-23, 72070 Tübingen, Germany; olaf.kuehne@uni-tuebingen.de \\ 2 Geomatics Group, Institute of Geography, Ruhr University Bochum, Universitätsstraße 150, 44801 Bochum, \\ Germany; dennis.edler@rub.de \\ * Correspondence: corinna.jenal@uni-tuebingen.de; Tel.: +49-(0)7071-29-77535
}

Received: 13 October 2020; Accepted: 25 November 2020; Published: 30 November 2020

check for updates

\begin{abstract}
The significance of play in the construction of landscape involving the feedback relationships between social conventions and the individual and between the individual and physical space, contrastingly, has so far received only little scientific attention. Games, however, take on great significance in the process of socialization in order to introduce the socializing person into the interpretations, valuations, and practices of the social world, which applies correspondingly to landscape. Play is an essential element of comprehending the concept "landscape". Accordingly, this present essay deals with conceptual considerations of the function of games in relation to the social and individual construction of landscape. The theoretical framing of landscape will be carried out within the theory of the three landscapes, following Karl Popper's three worlds. This theoretical framing also involves fundamental considerations on the connection between games and landscapes, which will be illustrated in more detail by means of two case examples, i.e., model railroads and pinball landscapes. It is shown that the playful engagement with landscape takes place in two dimensions: On the one hand, role expectations, norms, and values associated with landscape are conveyed, thus providing guidance for individual construction and individual experience of landscape. On the other hand, landscape contingencies can be tested. They address norms of interpretation and evaluation of landscape that are considered as bound together. Moreover, innovations can be tested, which may have been established in the social understanding of landscape.
\end{abstract}

Keywords: game; play; landscape; popper; model railway landscape; pinball landscape; socialization

\section{Introduction}

If landscape is not primarily understood as a material object, but primarily as a social or individual construction, questions come into focus, such as how social interpretations and evaluations of landscape arise, how they acquire general validity, and how they are conveyed in the process of socialization (among many: Cosgrove 1984, 1985; Proshansky et al. 1983; Visscher and Bie 2008; Kühne 2008a; Stotten 2013). Indespensible elements of the socialization process are recreation time and games. With their help, the socializing individual is introduced to the roles, values, and norms of society and tests its possibilities and limits, in an arena where divergent activities are subject to fewer negative sanctions than in the "real world" (Mead 1910, 1934, 1980). Even beyond the process of socialization, games serve to create spaces of possibility, beyond "social reality". The significance of play in the construction of landscape, in the feedback relationships between social conventions and the individual, and between the individual and physical space has, however, been little discussed scientifically so far. Since the topic of "landscape" has already been investigated more intensively in the virtual world (also in the context of games) (e.g., at: Bassiouni and Hackley 2015; Stintzing et al. 2020; Edler et al. 
2018, 2019; Fontaine 2017a, 2017b, 2020a, 2020b; Beil et al. 2015), our case examples focus on material manifestations of abstracting spatial observations: model railroad landscapes and pinball machines (first investigations can be found at Edler 2020; Kühne and Schmitt 2012a, 2012b).

To put the research question in concrete terms: The article pursues a threefold objective. (1) It shows the suitability of the transfer by Karl Popper's three worlds for landscape research through further applications. (2) It addresses the relevance of games for landscape research. (3) It emphasizes the importance of playful processes around the individual's attention to landscape in relation to material objects, based on social patterns of interpretation and the evaluation of landscape. Furthermore, a set of polarities are derived from the theoretical framework to facilitate empirical access to the relationship between landscape and game. This is tested by means of two case examples, i.e., model railroad landscapes and pinball landscapes.

Regarding the structure of the article: This paper deals with conceptual considerations of the function of games in relation to the social and individual construction of landscape. We will first frame the theoretical framing in relation to landscape with the theory of three landscapes reproducing Karl Popper's Three Worlds Theory, before we look at the social meaning of games. We then formulate fundamental considerations concerning the connections between games and landscapes. These are explained in more detail by relating two case examples, model railway landscapes and pinball machine landscapes. Finally, the conclusion is dedicated to the contemplation of the results and further research needs within this context.

\section{The Theory of the Three Landscapes as the Basis for Further Considerations}

The theoretical approaches to landscape are diverse; until the positivist turn in the 1960s, they were primarily characterized by positivist ideas; in the 1980s, constructivist approaches gained ground in the social sciences and humanities. The representational view of positivist and constructivist approaches soon came under criticism, and representational approaches gained more importance, related to an updating of phenomenological approaches to landscape research (see in more details: Wylie 2007; Kühne 2019b; Winchester et al. 2003; Howard et al. 2019). The approach of the three landscapes based on Karl Popper's three worlds presented here is in line with current developments in post-representational theory formation.

The foundation of this essay is in landscape theory as developed in detail in previous publications (Kühne 2018a, 2019a, 2020a; Kühne and Jenal 2020a, 2020b). The "theory of the three landscapes" is conceptually based on the three world theory by Karl Popper (Popper [1984] 2018; Popper [1987] 2019; Popper 1973; Popper and Eccles 1977). In his theory, Popper assumes that there is not only a world of material objects (he calls it World 1), but also that of individual consciousness (World 2) and that of cultural contents (World 3). Each represents a reality of their own. The three worlds are not necessarily separate from each other:

1. They are connected by the fact that World 2 is influenced by World 1 and World 3; similarly, World 2, in turn, can influence Worlds 1 and 3 (for example, World 2 observes World 1 and in the course of socialization is introduced into the contents of World 3).

2. They are also connected through the existence of hybrids from different worlds. For example, a building can be understood constitutively as part of World 1 and World 3, since it would not exist without materiality, just as it would not exist without the culturally bound knowledge of the construction of buildings.

In the center of the connections of the Worlds 1 and 3 is always World 2, because human consciousness possesses a body itself (as part of World 1), which enables it to be active in World 1. The development of the contents of World 3 also depends on World 2. After all, the contents of World 3 require being updated by World 2 before they can be fed back into World 3. This central focus on individual consciousness can also be interpreted as Popper's expression for an open society, where individuals are given great freedom to develop themselves and also World 3 (Popper [1947] 
2011; Dahrendorf 1979, 2002). Before we can address the question of how landscape can be designed according to Karl Popper's three worlds, an intermediate step is necessary. As landscape ultimately is a special case of space-why, we will explain later. Conceptually, three spatial levels can be derived from the three worlds: the space of material objects in relational arrangement (Space 1), individual knowledge of and access to space as Space 2, and social notions of space, as Space 3.

Analogous to the Worlds 1 through 3 and Spaces 1 through 3, Landscapes 1 through 3 can also be created. Landscape 1 represents the material objects that are synthesized by Landscape 2 . The notions of Landscape 2, in turn, are based on social conventions representing Landscape 3. Accordingly, Landscapes 1-3 represent subsets of the Spaces 1-3 and, in general, Worlds 1-3. In the construction of Landscape 1 by individual bearers of Landscape 2, material objects are synthesized and symbolically or emotionally occupied according to certain internalized, especially aesthetic, but also functional and ecological social ideas from Landscape 3 (in general: Ipsen 2006; Burckhardt 2006). Space 1 is thus the material substrate that represents the starting point for the construction of Landscape 1. Thus, Landscape 1 is not only a part of Space 1, but becomes a "special case" (Kühne 2018c) of Space 1, due to its symbolic and/or emotional occupation. A hybridization with social and individual ideas takes place here (for more details see: Kühne 2020a). More on this in the following.

Analogous to Karl Popper's three worlds, the inscription of social conceptions in Landscape 1 is carried out by transformation through Landscape 2. However, the complexity of human landscape references requires a differentiation within landscape conceptions as well as their representations in Landscape 1 (see also with regard to spatial complexity also Papadimitriou 2021). The different constructs of landscape can be summarized with the suffix letters a, b, and c (Kühne 2020a). The letter "a" denotes the "normal domestic landscape", which is formed individually by the child's reference to the surrounding World 1. It is strongly charged by emotions (Kühne 2011; Nissen 1998; Stotten 2013; Jenal 2020; Stotten 2019). The normative idea of the relation between Landscape 2a and Landscape $1 \mathrm{a}$ is that of stability. With the suffix letter " $\mathrm{b}$ ", common-sense understandings of landscape can be understood. This refers to the social conventions of interpretation and evaluation of Landscape $3 \mathrm{~b}$, which are conveyed to the individual as Landscape $2 \mathrm{~b}$ during the socialization process. The expectation addressed to Landscape 1 in the b-mode is that it corresponds to social stereotypes of landscape (especially aesthetic ones) (Kühne 2008a; Aschenbrand 2017; Fontaine 2020a; Jenal 2019; Stotten 2015; Hokema 2015). The suffix letter "c" describes the "expert special knowledge" of landscape. This is mostly acquired in a landscape-related study (e.g., landscape architecture, geography, agricultural sciences, biology, etc.). These educated landscape interpretation and evaluation patterns are strongly technical and can differ from one another significantly (Wojtkiewicz 2015; Burckhardt 2004; Kühne 2008b, 2018b). The normative concepts under c-mode consideration in Landscape 1 are the equivalent of one's own professional ideas and are usually deficit-oriented. This leads to a mandate for action by each respective discipline (Gailing 2014; Stemmer et al. 2019). The modes of landscape construction are also subject to interference, including an impact of the c-mode on the b-mode to a greater extent than vice versa (Fontaine 2019; Kühne 2008b; Aschenbrand 2016; Kühne 2006).

The approach presented here is suitable for landscape research in general and for research into the relationship between landscape and play in particular: In general, it contributes to overcoming the dichotomy of constructivist and positivist approaches to landscape research. In addition, it can also be described as a post-representational approach, since it theoretically integrates the recursive process of material objects, social constructions, and individual contributions (Thrift 2008; Waterton 2013; Macpherson 2010). Thus, it represents an approach to overcoming the historically almost irreconcilable juxtaposition of materialistic-positivistic and social constructions of landscape. This implies placing the individual (Landscape 2) as a central element in the theoretical focus, as phenomenological approaches have not yet been anchored in the mainstream of landscape research (Wylie 2005, 2019). From these general aptitudes of the three-landscape approach for theoretically informed landscape research, special perspectives for the investigation of the connection between landscape and game arise. In games, the individual attention to what is called landscape (especially Landscape 1) is 
formed, tested, and finally internalized in Landscape 2, against the background of social patterns of interpretation and evaluation (Landscape 3). Since the rules of games are more explicit than those of other communication processes, here in relation to landscape, the investigation of games is particularly suitable for understanding social processes of socialization, internalization, and innovation, here in relation to landscape.

\section{The Social Significance of Games}

At first glance, it seems so simple, and people often intuitively recognize whether an activity is a "game" or "play" or not (Smith and Vollstedt 1985). However, what ultimately differentiates games from other activities and clearly characterizes it as a game is difficult to define, not only in everyday language, but also scientifically. This is also related to the "ambiguity of play" (Sutton-Smith 1997; see also Gordon 2008). For example, it cannot be clearly assigned whether certain behavior is intentional or an act as-if behavior, sincere or nonsense, an object or a toy, and much more. A further problem with regard to an approach to games exists, following Sutton-Smith (1997, p. vii): The fact that there is "so much implicit ideological rhetoric" in the field of game research shows that it has become difficult to have a largely objective approach to the field. Argumentation often relies on the underpinnings of "evolutionary normative prejudices of researchers" (Sutton-Smith 1997, p. 29).

The scientific preoccupation with games and plays only began during the end of the 18th century in the field of evolutionary research (Gordon 2008), until it was finally introduced to didactics, especially in the fields of psychology, pedagogy, and sociology (Sutton-Smith 1997; Oerter 2007; Coccoli et al. 2015; Stintzing et al. 2020). Until the 20th century, it was primarily focused on the play of (young) children, but it was not until the 1970s and 1980s that psychology and sociology began to approach the study of play in adulthood (e.g., Cohen 1985; Betcher 1981), which has gained a lot of interest up until today, especially in connection with computer games (Pánek et al. 2018; Scharpf 1997; Beil et al. 2018; Beil et al. 2015). However, beyond this, it has remained rather rudimentary in many cases, until today (cf. van Vleet and Feeney 2015a, 2015b)

In the early days of scientific consideration, a purely deterministic and utilitarian view of games often prevailed (Gordon 2008). As one of the most famous representatives, Freud [1920] (Freud [1920] 2013) interpreted the child's play as a possibility to escape from (educational) constraints and to live out tabooed impulses (aggression, sexuality, etc.). In this context, youthful play follows a principle of pleasure rather than a principle of reality (Freud [1920] 2013). Furthermore, the controversial so-called catharsis hypothesis gained importance, according to which the acting out of previously tabooed desires and drives by repetition in the game is a form of problem solving. It allows us to overcome unresolved everyday experiences and thus "add an active counterpart to the passive experience" (Oerter 2007, p. 12). Additionally, Piaget (1969) regarded play as a "defense" against socialization and "reality constraints", in the context of which "the adult world and general reality interfere with play", and the child instead enjoys a reality "that you have for yourself" (Piaget 1969, p. 216). The cultural historian Johan Huizinga, on the other hand, expanded the concept of play, which has been discussed in scientific debate in a rather pedagogical-psychological way, by adding the cultural-forming aspects of play. Moreover, he stated in his work "Homo Ludens" that cultural areas (e.g., economy, science, politics, religion, etc.) developed from playful modes of action. He considered them as institutionalized over the course of time through ritualization (see in detail, Huizinga 1938).

Up until today, a variety of game/play understandings have been developed, which emphasize and differently weight different characteristics, such as the intentionally free/intentionally unconscious, the voluntariness, intrinsic motivation, fun/joy/pleasure, quasi-reality/fictitiousness, etc. (see Kluge 1981; Mehringer and Waburg 2020). Game/play is also considered as a necessary condition for learning social techniques, such as language, social rules, conducting human relationships, (fine) motor skills, cognitive abilities, etc. (Hauser 2014, 2016). 
The psychologist and evolutionary biologist Gordon Burghardt worked out five criteria based on a series of empirical studies using the example of humans and animals which together describe game behaviors (Burghardt 1999, 2005, 2011):

1. Incomplete functionality: "... that the performance of the behavior is not fully functional in the form or context in which it is expressed" (Burghardt 2011, pp. 13-14).

2. Positive activation: " ... that the behavior is spontaneous, voluntary, intentional, pleasurable, rewarding, reinforcing, or autotelic" (Burghardt 2011, p. 14).

3. Act as if: " ... that it differs from strictly functional expressions of behavior structurally or temporally in at least one respect: incomplete [...], exaggerated, awkward, precocious, or involves behavior patterns with modified form, sequencing, or targeting" (Burghardt 2011, p. 14).

4. Repetition and Variation: "...that the behavior is performed repeatedly in a similar, but not rigidly stereotyped, form during at least a portion of the animal's ontogeny" (Burghardt 2011, p. 15).

5. "Relaxed field": "...that the behavior is initiated when an animal is adequately fed, clothed, healthy, and not under stress [...] or intense competing systems" (Burghardt 2011, p. 16).

Through game/play, individuals-the player as well as the creator and landscape researcher-acquire important physical, psychological, cognitive, and social skills, but also certain sets of rules as necessary conditions for shaping their lives, providing opportunities for retreat, regeneration, and processing as well as (positive) stimulation and space for creative behavior and solutions, always with the option of being able to get out of the game at any time and start again or to realign conditions of play itself, which is often in contrast to non-play/non-game situations.

\section{Landscape and Game-Basic Considerations}

As has been emphasized in the previous section, games in the process of socialization have a great importance in introducing the socializing person into the interpretations, valuations, and practices of the social world. Similarly, this also applies to landscape: Landscape is not a term that can be understood by humans through a mediated view from an object, such as a meadow. Landscape is a complex term. To recognize landscape in a Space 1 means a synthesis of different material objects and object constellations with socially shared symbolic occupations and, finally, individual attributions in addition or demarcation to socially shared interpretations and evaluations. To learn complex concepts, the individual (World 2) must therefore be introduced to the world of social interpretations and evaluations (World 3). In the context of landscape: In order to be able to recognize a Landscape 1 in Space 1 as part of World 1, a Landscape 2 must be created based on the contents of Landscape 3. This means that the contents of Landscape 3 must be socialized in Landscape 2, the individual must internalize them in order to be able to understand Landscape 1 as unquestionably given (objectivation; in general: (Berger and Luckmann 1966; Tillmann 2007; Mühler 2008); in the context of landscape: (Visscher and Bie 2008; Stotten 2013; Nissen 1998; Kühne 2008a)). Nevertheless, it is also capable of changing social ideas of landscape (Landscape 3) (innovation). In this interrelationship, the playful and/or playful approach to landscape can become significant. On the one hand, rules for the construction of landscape (socialization) can be conveyed and tested here; on the other hand, innovative understandings of landscape can be developed.

While in "play", landscape-if at all constructed as such-takes on a more scenic function; in "game", there are clearer references to landscape (in the different dimensions). However, game also has a special meaning in the creation of Landscape 2: the peer group has a high significance in the appropriation of "landscape". This is not so much in the contemplative observation of space to landscape, but rather in a more aggressive use through playful experiences, especially in the sense of game according to Mead [1968] (Mead [1968] 1975); see also: (Kost 2017; Kühne 2008b; Nissen 1998). Play is an essential element of learning the term "landscape". A concept which, due to its complexity, must be successively learned (and experienced) and thus becomes a "significant symbol" as a result of the "taking in of the social organization of the outside world" (Mead 1980, p. 280). 
For landscape research, it is possible to derive varying degrees of the meaning of landscape in game (based on the investigations of the landscape references in films and Internet videos (Kühne 2020b; Kühne and Weber 2015; Lukinbeal 2005, 2012; Escher and Zimmermann 2001; Zimmermann 2019; Kühne and Schönwald 2015)):

I. Landscape has no meaning for the game.

II. Landscape has the function of scenery and provides a setting for the game (often in the manner Landscape 1, for example in the hide-and-seek game).

III. Landscape has the function of conveying the authenticity of the game plot (e.g., in computer games involving car races or in many strategy-oriented board games).

IV. Landscape is constitutive for the game, i.e., the game is related to the creation or design of landscape (e.g., in computer games like SimCity).

While the relationships between Landscape 2 and 1 dominate in the meaning ii, the level of Landscape 3 comes to the fore via the meaning iii to the meaning iv. Here, social stereotypes (b-mode) are updated, in some cases questioned. C-mode gains outstanding importance, as experts frame the possibilities and limits of the individual's influence on the design of Landscape 1. Expert influences relate to the conscious explicit construction of the game for the purpose of socializing certain ideas about landscape (for example, the aestheticization of old industrial objects), the diffusion of certain general notions of landscape-related norms (for example, the dissemination of ecological knowledge), the programming of games, and the associated rule-setting of what is and is not possible in the game, etc.

Besides the intensity of the meaning of landscape for, and in, games and the degree of expert influence on the construction of landscape in the game, two poles of games can generally be described: those that take place in the material space of Landscape 1 and those that represent a virtual construction of landscapes. Through the development of augmented reality (AR), the dichotomy became a polarity, i.e., the "classical Landscape 1" and virtual elements can be combined (as in Pokémon Go) or Landscape 1 can be simulated and modified virtually (Edler and Kühne 2019; Edler et al. 2018). The dichotomy describes two separate realms of existence or statements, i.e., an either-or presumption. The polarity refers to realms of existence or statements, between which transitions can be found, i.e., to a quite differentiated both/and. If a new Landscape 1-3 hybrid has already been created by the generation of virtual landscapes, the emergence of augmented reality means a further hybridization stage, namely that of Landscape 1 with that of virtual Landscape 1-3 hybrids.

Furthermore, a greater polarity can be found in relation to the meaning of landscape in games, i.e., a polarity between concreteness and abstractness. While the use of a "classical Landscape 1" always shows a high degree of concreteness, the degree of concreteness or abstraction in material or virtual creations of landscape can vary considerably, from slight idealizations and more or less true-to-scale reductions to geometric abstractions.

While computer-related games in virtual reality (VR) and AR as a form of game located at the pole of the virtual construction of landscapes have been increasingly and intensively dealt with (cf. Beil et al. 2015, 2018; Koebel 2017; Squire 2002; Fontaine 2017b, 2020a; Barab and Squire 2004; Wolf and Perron 2014), studies on games that take place at the second pole-material space-are rather underrepresented. In the following, both games in material space (e.g., a model railroad) and those with a low degree of hybridization (e.g., pinball machines) are used and examined along four polarities. These can be derived from the statements made so far about game and landscape:

1. Significance of landscape for games from non-existent to constitutive.

2. Degree of expert influence on the design of the relationship between game and landscape, from non-existent to high.

3. Polarity of materiality and virtuality.

4. The degree of concreteness and, conversely, abstraction. 
5. On the basis of these polarities, developed from the theoretical framework, the two case studies are examined below, also in connection with the question whether the polarity profile can form a starting point for a further and systematic investigation of the relationship between landscape and game.

\section{Empirical Case Examples}

\subsection{The Physical Manifestation of Landscape Stereotypes: The Model Railroad}

Landscape plays a central role in the design of model railroads; this is exhibited by our own empirical studies contrasting both a qualitative and quantitative investigation of the model railway literature and qualitative interview-based investigations ${ }^{1}$ (Kühne 2018b; Kühne and Schmitt 2012a, 2012b; Kühne 2008b). According to the conventions applicable in the discourse of model railroaders, this not only performs the function of serving as a backdrop for the railroad facilities and train operation, but also serves to legitimize the chosen "theme" of the model railroad. The operation of a large central station is legitimized by the (at least generalized) representation of a large city and not that of a hamlet, presenting an intensive freight train operation with industrial structures and industrial track systems. The preference for low mountain ranges lies in the legitimation for an intricate routing, thus accommodating the limited space (and budget), which makes a straight-line route difficult (one kilometer of track in the popular model railway scale H0 already means a track length of $11.5 \mathrm{~m}$ ).

In the following, the other polarities worked out above are investigated, as they are discussed and negotiated within the hobby community of model railroaders (Swales 1990; Borg 2003). This generates-like in all discussion communities-a complex system of conventions, which contain instructions for the design of model railroads in general and model railway landscapes especially. The goal is to achieve a "credible" symbiosis between route planning and landscape design. By means of "credibility", the model railway landscape becomes a distinguishing feature between the "serious" model railroader and the "playground train operator". Not only is the spatial dimension of model railroads serving the distinctive generation of an expert discourse, but also the temporal dimension, as a claim to "epochal purity", is formulated. The material to be found on the model railroad (from locomotives to buildings to painted figures) is selected in the same way as it would be found together on the actual original version. This means that a US diesel locomotive is just as undesirable on a layout modeled after a German low mountain range of the early 1960s (Epoch III) as the model of a current electric car. However, even a claim towards attention to detail that is understood as exaggerated is punished with the withdrawal of social recognition within the discourse: the "rivet counter" and the "page counter". The former addresses an exaggerated demand for fidelity of detail in rolling stock (e.g., by comparing the number of rivets depicted on locomotives of the actual original with those of the model), the latter does so in relation to landscape design.

Both the model railroaders interviewed and the model railroad related literature show a preference for "historical cultural landscapes". Implicitly, and more often explicitly, the romanticization of a landscape of bygone days is accompanied by a longing for an (seemingly) idyllic, often rural community life (Vicenzotti 2006; Kühne 2019b). This is, however, in contradiction to the legitimization of large railroad facilities and the associated necessity of representing urban structures. It regulates the conflict regarding how both urban and rural Landscapes 1-in a highly generalized form-are represented. The longing for security and predictability (Bauman 1995; Baumann 2009) is also documented in the preferred chronological classification of plants: what is often referred to as Epoch III (the 1950s and early 1960s, in West Germany also the time of the so-called "economic miracle") dominates.

1 Quantitative and qualitative content analysis of 17 German-language publications with a total of 95 sample installations were carried out (Kühne 2008b), supplemented by a qualitative study based on guideline-controlled interviews with 25 members from four model railway associations in Saarland (Kühne and Schmitt 2012a, 2012b). The methodology is described in detail in the cited literature. 
In accordance with the claim of creating a "perfect world", objects and constellations of objects that are generally classified as "ugly" are largely avoided, unless they are necessary to legitimize the theme of the model railroad (e.g., industrial plants), or these objects serve as a means of distinction, since a "realistic" depiction of Landscape 1 is being postulated (see also Figure 1; in more detail at: Kühne and Schmitt 2012b).

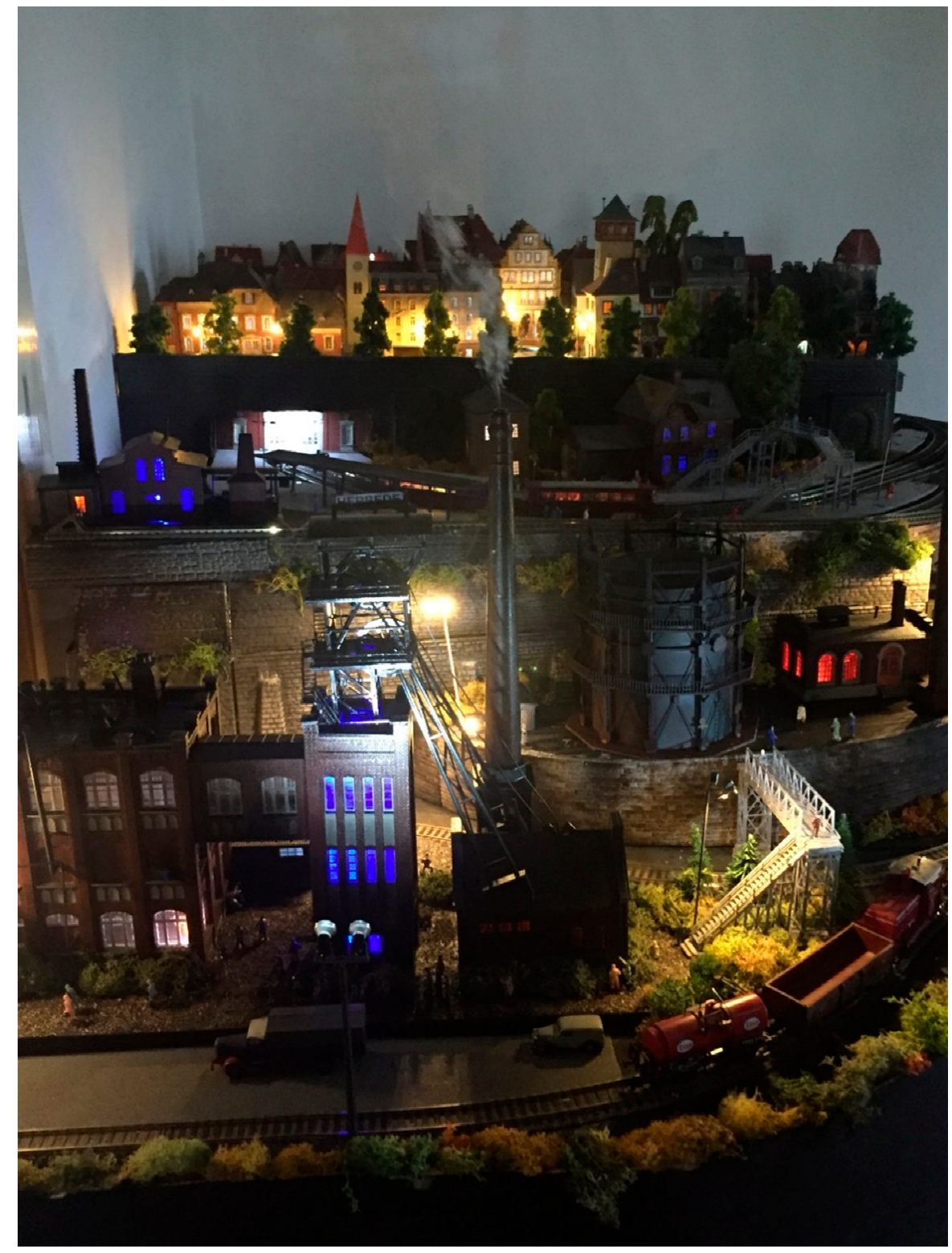

Figure 1. Detail of a model railway landscape, characterized by the builder's preference for old industrial plants; at the same time, the industrial plants legitimize extensive goods operation, the urban settlement in the background is used for passenger service, the reproduction of the relief also serves to conceal the tracks inside the mountain, and the reproduction of buildings and vehicles links the plant to the early 1970s/late 1980s (created by author).

A social hierarchy of a "ruling class" exists, as well in the discourse of model railroaders (Bourdieu 2016), which decides on what can and cannot be represented in model landscapes (especially authors of model railway literature). They formulate the specifications of Landscape $3 c$, which the "middle class", most model railroaders, follow as Landscape $3 b$ so to be assigned to an alternative form of 
the "toy railroader" or "rivet or leaf counter" —this provided that they participate in the community discourse and are not pure "private railroaders", thereby avoiding discursive replication.

Regarding the polarities formulated above, the meaning of landscape in relation to model railroads can be summarized as follows:

1. The meaning of landscape is constitutive for the design of model railroads. It not only legitimizes the operation of the railroad, but also gives the setting a spatial and temporal framework.

2. The influence of experts (upon landscapes with the suffix " $c$ ") is high; they define what, how, and in which context aspects are desirable or not desirable concerning the design of model railroads.

3. In terms of the polarity of materiality and virtuality, model trains fluctuate around the pole of the material, albeit in a miniaturization. However, because of technical, financial, and spatial limitations, this miniaturization is often not true to scale.

4. The model railroad landscape combines a material concreteness with social and technical abstractions: the model railroad is an expression of generalizations and stereotyping as well as romanticization.

\subsection{Of Scenic Stereotypes and How to Overcome Them: The Landscapes of Pinball Machines}

Landscapes also play an important role in retro games, such as modern pinball machines. Traditional pinball machines and their ancestors are abstract games. They are focused on score and do not "tell" a spatial story. They consist of wooden playfields with holes leading to different scoring points when a ball falls into them (originating from the French game "Bagatelle"). In modern pinball machines (after electromechanical features had begun to be implemented in the 1940s), the player's focus is still on an abstract material object (commonly a metallic ball, also referred to as the "silver ball"). It is, however, moving across a vivid and vibrant playfield. The playfield consists of interactive and audio-visually animated objects reacting to physical contact with the ball. Winning is associated with a high score acquired by hitting targets (randomly or in order). The (otherwise "endless") game is lost as soon as the ball falls into a drain. These interactions with "physical targets" on the animated playfield are aspects of the game that invite a more specific and detailed (concrete) spatial story.

Many pinball themes refer to existing physical landscapes. The playfield, the targets on the playfield, the backglass image, and other graphics on the pinball machines are used to represent existing landscapes. They are often bound to urban leisure time activities, a motif of travel (associated with escapism), or stereotypical rural and coastal holiday destinations (Edler et al. 2020). Examples dealing with stereotypical holiday sceneries are the 1940s and 1950s pinball machines South Pacific (Genco 1950), Caribbean (Genco 1948), and Wisconsin (United 1948). The players are invited to take part in a summer atmosphere, accompanied by images of enjoyment, recovery, and love.

These landscapes are translated into materialized objects and object-based events in the pinball playfield. As with a (cartographic) map or a map-like representation, a filtered ("generalized") impression of the "real" material landscape is composed of representative materialized objects or object categories (see also Section 1). These static objects can be bound to animations, as known from multimedia cartography (see, e.g., Lammert-Siepmann et al. 2017; Peterson 1995; Laakso and Sarjakoski 2010).

The "materialized translation" of Landscape 1 is not only used to represent a landscape factually. In the context of a game, unlike topographic maps and very factual landscape representations around model trains, these pinball machines are intended to evoke individual positive associations concerning the represented landscapes, in the sense of Landscape 2. The rapidly changing game (of skill) increases the positive atmosphere by conveying an entertainment factor. Moreover, the velocity of the game may "melt with" the pinball theme, such as in large-scale sceneries of urban entertainment. An example would be a sports arena, such as a pinball representation of an American Football stadium, a race-track, or an ice-skating arena (see Figure 2). 


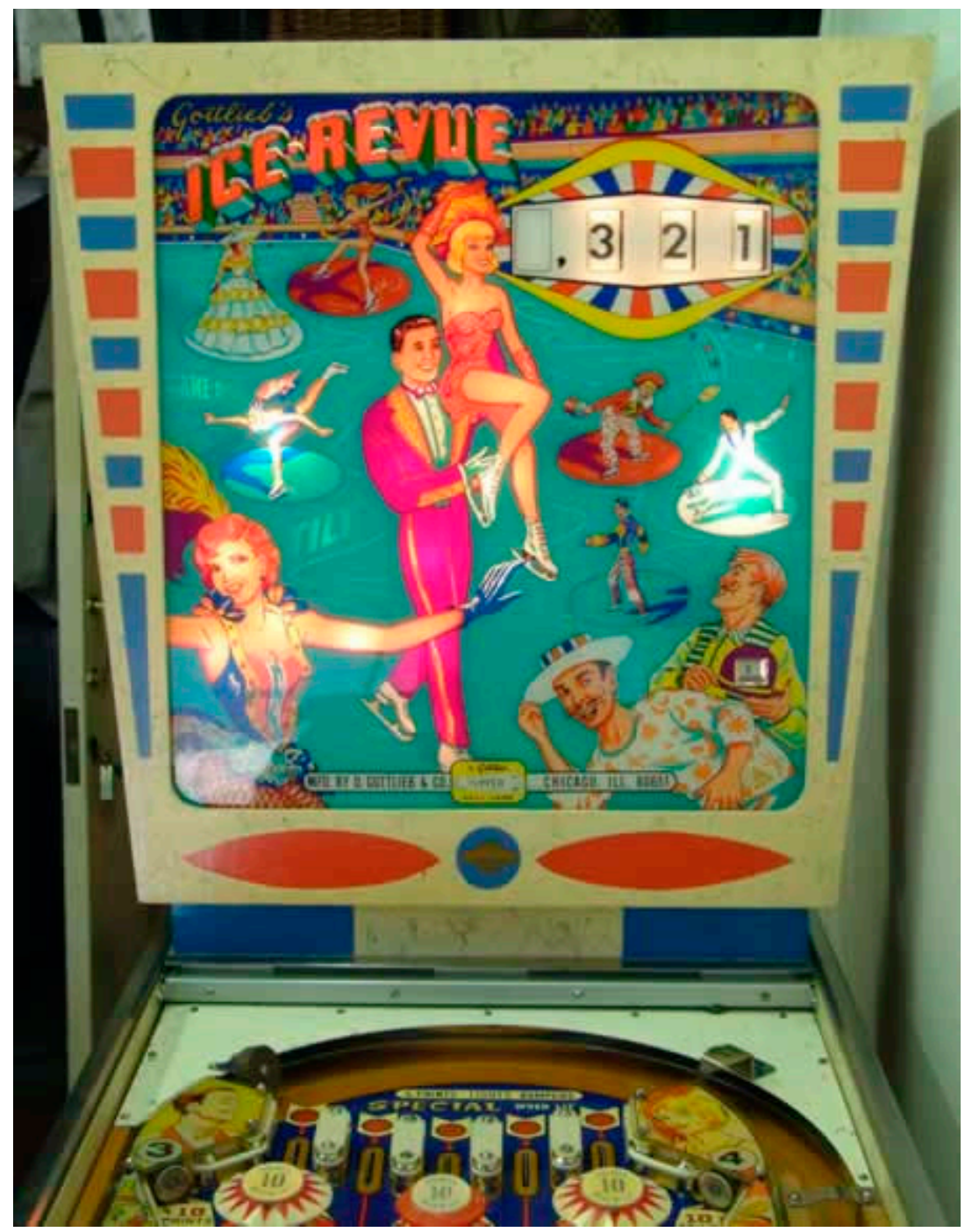

Figure 2. A backglass image (Ice Revue, released by Gottlieb in 1965), representing urban culture in an indoor-sports environment; used with permission (C) Ros-vintagepinballs.co.uk.

The cultural meaning of pinball-based landscapes (Landscape 3) is emphasized via specific groups of pinball machine themes. Pinball manufacturers released pinball machines dealing with festivals and events, such as Oktoberfest (American Pinball 2018), Circus (Williams 1994) and Carnival (Bally 1957). They transport cultural conventions in large-scale representations of these festive landscapes. This also applies for pinball machines addressing musical themes, especially rock music and heavy metal. The landscape representation in the pinball playfield appears like a concert stage where the musical genre and the stories and histories of bands and artists are emphasized. The artists can be regarded as people who shaped others. They had an impact on society, and they were also often associated with existing urban landscapes, such as Elvis (Las Vegas) or The Beatles (Liverpool).

Of course, expert knowledge is required to decode and understand specific meanings and landscape creations transported by such examples of pinball machines. Even more specific expert knowledge is required when pinball themes are bound to examples of popular culture, such as literary fiction, comic books, and movies. The "diegetic worlds" (Wolf 2014, p. 125) of these stories can only be fully understood if players have already been confronted with the original media source. Players would not understand the meaning of the Falling Towers in Barad-dûr or The Paths of the Dead through the White Mountains in a (spatial) pinball game, without having seen or read The Lord of the Rings. 
Following the polarities developed in the previous paragraphs, landscape in the pinball game can be classified as follows:

1. Pinball games are arranged in the material world.

2. The importance of landscape is high, but it is not constitutive, as a pinball game operates successfully without a landscape contextualization.

3. The expert influence is high, especially in terms of the technical implementation.

4. The degree of concreteness on the one hand and abstractness on the other hand varies between pinball machines. There are both concrete and abstract representations.

\section{Conclusions}

The present contribution has made a landscape operationalization out of a general theoretical framework following Karl Popper's theory of three worlds and tested it empirically by means of a playful approach to landscape. In relation to the threefold objective formulated at the beginning of the paper, the following can be stated: (1) Karl Popper's three worlds can be profitably applied to landscape research, as it provides a post-representational framework for the theoretical framing of the processes of feedback from Landscape 2 to Landscape 3 and Landscape 1. (2) The relevance of games for landscape research became clear; games allow a contingent access to landscape-related conventions. (3) The research on the importance of game for the construction of landscape thus contributes to the understanding of individual landscape constructions (Landscape 2) against the background of socialization, incorporation, and innovation. These aspects are explained in more detail below.

Landscape 2 is created by conveying the conventions of Landscape 3 in combination with the perception of elements of Space 1 synthesized as Landscape 1. The playful engagement with landscape takes place in two dimensions: one aspect refers to the role expectations, norms, and values associated with landscape that are conveyed, thus providing guidance for individual construction and the individual experience of landscape. Conversely, landscape contingencies can be tested, the designed Landscape 1-3 hybrid can challenge norms of interpretation and evaluation of landscape that are considered binding; innovations can be tested that, if necessary, become established in the social understanding of landscape (Landscape 3).

In games, landscape can have a different meaning. Landscape can be completely insignificant for games (for example, in card games), but it can also be constitutive (as in computer games, in which the real-time transformation of spaces forms a basis). Landscape is also constitutive in the design of model railroads, as the case study in Section 5.1 has shown. There are numerous gradations in between. Additionally, the degree of expert influence on the design of the relationship between game and landscape can vary from non-existent to high, whereby the expert influence is to be further differentiated. It alternatively refers to interpretations about landscape (how can a landscape norm be achieved?), and additionally to the technical fundamentals of landscape generation (for example the programming of animation logics based on user interaction in pinball games, or also in programmed computer games). Beyond that, the polarity of materiality and virtuality is found. It describes whether landscape is located in material space and whether it is material or virtual or something in between. Moreover, the degree of concreteness and, conversely, of abstractness varies beyond that. Especially when creating landscape for the game: is landscape designed as close as possible to the referenced source, or is an abstract reference made?

In the case examples, it became clear that the connection between landscape and game can be examined based on polarity profile developed in this article. In this respect, these polarities can serve as a basis for further investigation involving the field of the relationship between game and landscape, as explored here. Thus, among others, the following elements appear relevant: the meaning of Space 1 as Landscape 1 in terrain games, the abstraction of landscape in board games, and the field of contingent landscape constructions in virtual landscapes. A special potential lies in the extension of the methodological spectrum from non-reactive procedures to reactive procedures, not only with 
regard to users (as in Fontaine 2017b), but also in relation to the producers of scenic contexts in games, such as game designers in both the analog and digital world.

The study of the relationship between game and landscape not only provides a more detailed insight into the processes of the feedback generation of Landscape 2 and 3, as well as the experience and modification/generation of Landscape 1. It can also be seen as an example of the importance of games in the process of lifelong socialization.

Author Contributions: Conceptualization, O.K., C.J., D.E; Methodology, O.K., C.J., D.E.; Writing—Original draft preparation, O.K., C.J., D.E.; Writing—review and editing, O.K., C.J., D.E.; Visualization, O.K., C.J., D.E. All authors have read and agreed to the published version of the manuscript.

Funding: This research received no external funding.

Conflicts of Interest: The authors declare no conflict of interest.

\section{References}

Aschenbrand, Erik. 2016. Einsamkeit im Paradies. Touristische Distinktionspraktiken bei der Aneignung von Landschaft. Berichte. Geographie und Landeskunde 90: 219-34.

Aschenbrand, Erik. 2017. Die Landschaft des Tourismus: Wie Landschaft von Reiseveranstaltern Inszeniert und von Touristen Konsumiert Wird. Wiesbaden: Springer VS.

Barab, Sasha, and Kurt Squire. 2004. Replaying history: Engaging urban underserved students in learning world history through computer simulation games. In ICLS '04: Proceedings of the 6th International Conference on Learning Sciences. Edited by Noel Eneydy, Yasmin B. Kafai and William A. Sandoval. Santa Monica: International Society of the Learning Sciences, pp. 505-12.

Bassiouni, Dina H., and Chris Hackley. 2015. Digital Socialisation: Children's Experiences as Consumers of Video Games. In Proceedings of the 40th Annual Macromarketing Conference. Edited by Clifford Shultz II, Ramond Benton and Olga Kravets. Chicago: Macromarketing Society, Inc., pp. 189-95.

Bauman, Zygmunt. 1995. Life in Fragments: Essays in Postmodern Morality. Oxford: Blackwell.

Baumann, Zygmunt. 2009. Gemeinschaften. Auf der Suche Nach Sicherheit in Einer Bedrohlichen Welt. Frankfurt: Suhrkamp.

Beil, Benjamin, Gundolf S. Freyermuth, and Lisa Gotto. 2015. New Game Plus: Perspektiven der Game Studies. Genres-Künste-Diskurse. Bielefeld: transkript.

Beil, Benjamin, Thomas Hensel, and Andreas Rauscher. 2018. Game Studies. Film, Fernsehen, Neue Medien. Wiesbaden: Springer VS.

Berger, Peter L., and Thomas Luckmann. 1966. The Social Construction of Reality: A Treatise in the Sociology of Knowledge. New York: Anchor Books.

Betcher, R. William. 1981. Intimate Play and Martial Adaptation. Psychiatry 44: 13-33. [CrossRef] [PubMed]

Borg, Erik. 2003. Discourse community. ELT Journal 57: 398-400. [CrossRef]

Bourdieu, Pierre. 2016. La distinction: Critique Sociale du Jugement. Le Sens commun. Paris: Editions de Minuit.

Burckhardt, Lucius. 2004. Wer plant die Planung? Architektur, Politik und Mensch. Edited by Lucius Burckhardt. Berlin: Martin Schmitz Verlag.

Burckhardt, Lucius. 2006. Warum ist Landschaft schön? Die Spaziergangswissenschaft. Edited by Markus Ritter and Martin Schmitz. Kassel: Martin Schmitz Verlag.

Burghardt, Gordon M. 1999. Conceptions of play and the evolution of animal minds. Evolution and Cognition 5: $115-23$.

Burghardt, Gordon M. 2005. The Genesis of Animal Play: Testing the Limits. Cambridge/London: MIT Press.

Burghardt, Gordon M. 2011. Defining and Recognizing Play. In The Oxford Handbook of the Development of Play. Edited by Anthony D. Pellegrini. New York: Oxford University Press, pp. 9-18.

Coccoli, Mauro, Iacono Saverio, and Gianni Vercelli. 2015. Applying gamification techniques to enhance effectiveness of video-lessons. Journal of e-Learning and Knowledge Society 11: 73-84.

Cohen, Erik. 1985. Tourism as play. Religion 15: 291-304. [CrossRef]

Cosgrove, Denis E. 1984. Social Formation and Symbolic Landscape. London: University of Wisconsin Press.

Cosgrove, Denis. 1985. Prospect, Perspective and the Evolution of the Landscape Idea. Transactions of the Institute of British Geographers 10: 45-62. [CrossRef] 
Dahrendorf, Ralf. 1979. Lebenschancen: Anläufe zur Sozialen und Politischen Theorie. Suhrkamp-Taschenbuch 559. Frankfurt: Suhrkamp.

Dahrendorf, Ralf. 2002. Über Grenzen: Lebenserinnerungen. München: C. H. Beck.

Edler, Dennis. 2020. Where Spatial Visualization Meets Landscape Research and "Pinballology": Examples of Landscape Construction in Pinball Games. KN-Journal of Cartography and Geographic Information 70: 55-69. [CrossRef]

Edler, Dennis, and Olaf Kühne. 2019. Nicht-visuelle Landschaften. In Handbuch Landschaft. Edited by Olaf Kühne, Florian Weber, Karsten Berr and Corinna Jenal. Wiesbaden: Springer VS, pp. 599-612.

Edler, Dennis, Olaf Kühne, Corinna Jenal, Mark Vetter, and Frank Dickmann. 2018. Potenziale der Raumvisualisierung in Virtual Reality (VR) für die sozialkonstruktivistische Landschaftsforschung. Kartographische Nachrichten 68: 245-54. [CrossRef]

Edler, Dennis, Julian Keil, Timo Wiedenlübbert, Melvin Sossna, Olaf Kühne, and Frank Dickmann. 2019. Immersive VR Experience of Redeveloped Post-industrial Sites: The Example of "Zeche Holland" in Bochum-Wattenscheid. KN-Journal of Cartography and Geographic Information 38: 1-18. [CrossRef]

Edler, Dennis, Corinna Jenal, and Olaf Kühne. 2020. Modern Approaches to the Visualization of Landscapes. Wiesbaden: Springer VS.

Escher, Anton, and Stefan Zimmermann. 2001. Geography meets Hollywood: Die Rolle der Landschaft im Spielfilm. Geographische Zeitschrift 89: 227-36.

Fontaine, Dominique. 2017a. Ästhetik simulierter Welten am Beispiel Disneylands. In Landschaftsästhetik und Landschaftswandel. Edited by Olaf Kühne, Heidi Megerle and Florian Weber. Wiesbaden: Springer VS, pp. 105-20.

Fontaine, Dominique. 2017b. Simulierte Landschaften in der Postmoderne: Reflexionen und Befunde zu Disneyland, Wolfersheim und GTA V. Wiesbaden: Springer VS.

Fontaine, Dominique. 2019. Landschaft in Schulbüchern. In Handbuch Landschaft. Edited by Olaf Kühne, Florian Weber, Karsten Berr and Corinna Jenal. Wiesbaden: Springer VS, pp. 641-50.

Fontaine, Dominique. 2020a. Landscape in computer games-the examples of GTA V and Watch Dogs 2. In Modern Approaches to the Visualization of Landscape. Edited by Dennis Edler, Corinna Jenal and Olaf Kühne. Wiesbaden: Springer VS, in printing.

Fontaine, Dominique. 2020b. Virtuality and Landscape. In Modern Approaches to the Visualization of Landscape. Edited by Dennis Edler, Corinna Jenal and Olaf Kühne. Wiesbaden: Springer VS, in printing.

Freud, Sigmund. 2013. Jenseits des Lustprinzips. Ditzingen: Reclam. First published 1920.

Gailing, Ludger. 2014. Kulturlandschaftspolitik: Die gesellschaftliche Konstituierung von Kulturlandschaft durch Institutionen und Governance. Planungswissenschaftliche Studien zu Raumordnung und Regionalentwicklung 4. Detmold: Rohn.

Gordon, Gwen. 2008. What is Play? In Search of a Universal Definition. Play and Culture Studies 8: 1-21.

Hauser, Bernhard. 2014. Spiel als notwendige Bedingung gelingender früher Sprachentwicklung. SAL-Bulletin 151: 5-11.

Hauser, Bernhard. 2016. Spielen: Frühes Lernen in Familie, Krippe und Kindergarten, 2nd ed. Suttgart: W. Kohlhammer $\mathrm{GmbH}$.

Hokema, Dorothea. 2015. Landscape is everywhere. The Construction of Landscape by US-American Laypersons. Geographische Zeitschrift 103: 151-70.

Howard, Peter, Ian Thompson, Emma Waterton, and Mick Atha. 2019. The Routledge Companion to Landscape Studies, 2nd ed. London/New York: Routledge.

Huizinga, Johan. 1938. Homo Ludens: Versuch einer Bestimmung des Spielelementes der Kultur. 3. Auflage. Basel: Akademie Verlagsanstalt Pantheon.

Ipsen, Detlev. 2006. Ort und Landschaft. Wiesbaden: VS Verlag für Sozialwissenschaften.

Jenal, Corinna. 2019. “Das ist kein Wald, Ihr Pappnasen!"-Zur sozialen Konstruktion von Wald: Perspektiven von Landschaftstheorie und Landschaftspraxis. Wiesbaden: Springer VS.

Jenal, Corinna. 2020. Visualizations of 'landscape' in protest movements: On exclusive and inclusive patterns of vision and interpretation using the example of resistance to the expansion of the electricity grid in Germany. In Modern Approaches to the Visualization of Landscape. Edited by Dennis Edler, Corinna Jenal and Olaf Kühne. Wiesbaden: Springer VS, in printing. 
Kluge, Norbert. 1981. Spielen und Erfahren: Der Zusammenhang von Spielerlebnis und Lernprozess. Bad Godesberg: Klinkhardt.

Koebel, Greg. 2017. Simulating the Ages of Man: Periodization in Civilization V and Europa Universalis IV. Loading. The Journal of the Canadian Game Studies Association 10: 60-76.

Kost, Susanne. 2017. Raumbilder und Raumwahrnehmung von Jugendlichen. In Landschaftsästhetik und Landschaftswandel. Edited by Olaf Kühne, Heidi Megerle and Florian Weber. Wiesbaden: Springer VS, pp. 69-85.

Kühne, Olaf. 2006. Soziale Distinktion und Landschaft. Eine landschaftssoziologische Betrachtung. Stadt+Grün 12: 42-45.

Kühne, Olaf. 2008a. Die Sozialisation von Landschaft-sozialkonstruktivistische Überlegungen, empirische Befunde und Konsequenzen für den Umgang mit dem Thema Landschaft in Geographie und räumlicher Planung. Geographische Zeitschrift 96: 189-206.

Kühne, Olaf. 2008b. Distinktion-Macht-Landschaft: Zur Sozialen Definition von Landschaft. Wiesbaden: VS Verlag für Sozialwissenschaften.

Kühne, Olaf. 2011. Heimat und sozial nachhaltige Landschaftsentwicklung. Raumforschung und Raumordnung 69: 291-301. [CrossRef]

Kühne, Olaf. 2018a. Die Landschaften 1, 2 und 3 und ihr Wandel: Perspektiven für die Landschaftsforschung in der Geographie-50 Jahre nach Kiel. Berichte. Geographie und Landeskunde 3-4: 217-31.

Kühne, Olaf. 2018b. Landscape and Power in Geographical Space as a Social-Aesthetic Construct. Dordrecht: Springer International Publishing.

Kühne, Olaf. 2018c. Landschaftstheorie und Landschaftspraxis: Eine Einführung Aus Sozialkonstruktivistischer Perspektive. 2. Aktualisierte und überarbeitete Auflage. Wiesbaden: Springer VS.

Kühne, Olaf. 2019a. Der dreifache Landschaftswandel. Forum Raumentwicklung 1: 18-19.

Kühne, Olaf. 2019b. Landscape Theories: A Brief Introduction. Wiesbaden: Springer VS.

Kühne, Olaf. 2020a. Landscape Conflicts: A Theoretical Approach Based on the Three Worlds Theory of Karl Popper and the Conflict Theory of Ralf Dahrendorf, Illustrated by the Example of the Energy System Transformation in Germany. Sustainability 12: 6772. [CrossRef]

Kühne, Olaf. 2020b. The Social Construction of Space and Landscape in Internet Videos. In Modern Approaches to the Visualization of Landscape. Edited by Dennis Edler, Corinna Jenal and Olaf Kühne. Wiesbaden: Springer VS, in printing.

Kühne, Olaf, and Corinna Jenal. 2020a. Baton Rouge-The Multivillage Metropolis: A Neopragmatic Landscape Biographical Approach on Spatial Pastiches, Hybridization, and Differentiation. Wiesbaden: Springer VS.

Kühne, Olaf, and Corinna Jenal. 2020b. The threefold landscape change-basic considerations, conflicts and potentials of virtual landscape research. In Modern Approaches to the Visualization of Landscape. Edited by Dennis Edler, Corinna Jenal and Olaf Kühne. Wiesbaden: Springer VS, in printing.

Kühne, Olaf, and Johannes Schmitt. 2012a. Landschaft und Modelleisenbahn: Zur Erzeugung von Landschaft im Spannungsfeld von ästhetischen Präferenzen, Anpassung an das Vorbild und Technikbezogenheit. Zoll+. Österreichische Schriftenreihe für Landschaft und Freiraum 22: 108-11.

Kühne, Olaf, and Johannes Schmitt. 2012b. Spiel mit Landschaft-Logiken der Konstruktion von Landschaft in der Diskursgemeinschaft der Modelleisenbahner. Berichte zur Deutschen Landeskunde 86: 175-94.

Kühne, Olaf, and Antje Schönwald. 2015. San Diego: Eigenlogiken, Widersprüche und Hybriditäten in und Von, America's Finest City'. Wiesbaden: Springer VS.

Kühne, Olaf, and Florian Weber. 2015. Der Energienetzausbau in Internetvideos-eine quantitativ ausgerichtete diskurstheoretisch orientierte Analyse. In Landschaftswandel-Wandel von Machtstrukturen. Edited by Susanne Kost and Antje Schönwald. Wiesbaden: Springer VS, pp. 113-26.

Laakso, Mari, and Tiina L. Sarjakoski. 2010. Sonic Maps for Hiking-Use of Sound in Enhancing the Map Use Experience. The Cartographic Journal 47: 300-7. [CrossRef]

Lammert-Siepmann, Nils, Anne-Kathrin Bestgen, Dennis Edler, Lars Kuchinke, and Frank Dickmann. 2017. Audiovisual Communication of Object-Names Improves the Spatial Accuracy of Recalled Object-Locations in Topographic Maps. PLoS ONE 12. [CrossRef]

Lukinbeal, Christopher. 2005. Cinematic Landscapes. Journal of Cultural Geography 23: 3-22. [CrossRef] 
Lukinbeal, Christopher. 2012. “On Location” Filming in San Diego County from 1985-2005: How a Cinematic Landscape Is Formed Through Incorporative Tasks and Represented Through Mapped Inscriptions. Annals of the Association of American Geographers 102: 171-90. [CrossRef]

Macpherson, Hannah. 2010. Non-Representational Approaches to Body-Landscape Relations. Geography Compass 4: 1-13. [CrossRef]

Mead, George Herbert. 1975. Geist, Identität und Gesellschaft aus der Sicht des Sozialbehaviorismus, 2nd ed. Edited by Charles W. Morris. Suhrkamp-Taschenbuch Wissenschaft 28. Frankfurt: Suhrkamp. First published 1968.

Mead, George Herbert. 1910. Social consciousness and the consciousness of meaning. Psychological Bulleti 7: 397-405. [CrossRef]

Mead, George Herbert. 1934. Mind, Self, and Society: From the Standpoint of a Social Behaviorist. Chicago: University of Chicago Press.

Mead, George Herbert. 1980. Gesammelte Aufsätze: Band 1. Edited by Hans Joas. Frankfurt: Suhrkamp.

Mehringer, Volker, and Wiebke Waburg. 2020. Das Projekt SAKEF-Theoretische und konzeptionelle Überlegungen zur Spielzeugbewertung und Spielzeugauswahl. In Spielzeug, Spiele und Spielen: Aktuelle Studien und Konzepte. Edited by Volker Mehringer and Wiebke Waburg. Research. Wiesbaden: Springer VS, pp. 15-36.

Mühler, Kurt. 2008. Sozialisation: Eine Soziologische Einführung. Paderborn: W. Fink.

Nissen, Ursula. 1998. Kindheit, Geschlecht und Raum: Sozialisationstheoretische Zusammenhänge Geschlechtsspezifischer Raumaneignung. Weinheim: Beltz Juventa.

Oerter, Rolf. 2007. Zur Psychologie des Spiels. Psychologie und Gesellschaftskritik 31: 7-32.

Pánek, Jiří, Alex Gekker, Sam Hind, Jana Wendler, Chris Perkins, and Sybille Lammes. 2018. Encountering Place: Mapping and Location-Based Games in Interdisciplinary Education. The Cartographic Journal 55: 285-97. [CrossRef]

Papadimitriou, Fivos. 2021. Spatial Complexity: Theory, Mathematical Methods and Applications. Cham: Springer Nature.

Peterson, Michael P. 1995. Interactive and Animated Cartography. Englewood Cliffs: Prentice-Hall.

Piaget, Jean. 1969. Das Erwachen der Intelligenz Beim Kinde. Stuttgart: Klett-Cotta.

Popper, Karl R. 2011. The Open Society and Its Enemies. Abingdon: Routledge. First published 1947.

Popper, Karl R. 2018. Alle Menschen sind Philosophen. München: Piper, Herausgegeben von Heidi Bohnet und Klaus Stadler. First published 1984.

Popper, Karl R. 2019. Auf der Suche Nach Einer Besseren Welt: Vorträge und Aufsätze aus Dreißig Jahren. München: Piper. First published 1987.

Popper, Karl Raimund. 1973. Objektive Erkenntnis: Ein evolutionärer Entwurf. Hamburg: Hoffmann und Campe. Popper, Karl R., and John C. Eccles. 1977. Das Ich und sein Gehirn. München: Piper.

Proshansky, Harold M., Abbe K. Fabian, and Robert Kaminoff. 1983. Place-identity: Physical world socialization of the self. Journal of Environmental Psychology 3: 57-83. [CrossRef]

Scharpf, Fritz W. 1997. Games Real Actors Play: Actor-Centered Institutionalism in Policy Research. Boulder: Routledge. Smith, Peter K., and Ralph Vollstedt. 1985. On Defining Play: An Empirical Study of the Relationship between Play and Various Play Criteria. Child Development 56: 1042-50. [CrossRef]

Squire, Kurt. 2002. Cultural Framing of Computer/Video Games. Game Studies 2. Available online: http: //www.gamestudies.org/0102/squire/ (accessed on 21 September 2020).

Stemmer, Boris, Sven Philipper, Nicola Moczek, and Jonas Röttger. 2019. Die Sicht von Landschaftsexperten und Laien auf ausgewählte Kulturlandschaften in Deutschland-Entwicklung eines Antizipativ-Iterativen Geo-Indikatoren-Landschaftspräferenzmodells (AIGILaP). In Landschaftskonflikte. Edited by Karsten Berr and Corinna Jenal. Wiesbaden: Springer VS, pp. 507-34.

Stintzing, Maximilian, Stephan Pietsch, and Ute Wardenga. 2020. How to Teach "Landscape" through Games? In Modern Approaches to the Visualization of Landscape. Edited by Dennis Edler, Corinna Jenal and Olaf Kühne. Wiesbaden: Springer VS, in printing.

Stotten, Rike. 2013. Kulturlandschaft gemeinsam verstehen-Praktische Beispiele der Landschaftssozialisation aus dem Schweizer Alpenraum. Geographica Helvetica 68: 117-27. [CrossRef]

Stotten, Rike. 2015. Das Konstrukt der bäuerlichen Kulturlandschaft: Perspektiven von Landwirten im Schweizerischen Alpenraum. alpine space-man \& environment 15. Innsbruck: Innsbruck University Press. 
Stotten, Rike. 2019. Kulturlandschaft als Ausdruck von Heimat der bäuerlichen Gesellschaft. In Heimat: Ein Vielfältiges Konstrukt. Edited by Martina Hülz, Olaf Kühne and Florian Weber. Wiesbaden: Springer VS, pp. 149-62.

Sutton-Smith, Brian. 1997. The Ambiguity of Play. Cambridge: Harvard University Press.

Swales, John. 1990. Genre Analysis: English in Academic and Research Settings. 12. Auflage. Cambridge: Cambridge University Press.

Thrift, Nigel. 2008. Non-Representational Theory: Space, Politics, Affect. International library of sociology. Abingdon/New York: Routledge.

Tillmann, Klaus-Jürgen. 2007. Sozialisationstheorien: Eine Einführung in den Zusammenhang von Gesellschaft, Institution und Subjektwerdung, 15th ed. Rororo Rowohlts Enzyklopädie 55476. Reinbek bei Hamburg: Rowohlt.

van Vleet, Meredith, and Brooke C. Feeney. 2015a. Play Behavior and Playfulness in Adulthood. Social and Personality Psychology Compass 9: 630-43. [CrossRef]

van Vleet, Meredith, and Brooke C. Feeney. 2015b. Young at Heart: A Perspective for Advancing Research on Play in Adulthood. Perspectives on Psychological Science 10: 639-45. [CrossRef]

Vicenzotti, Vera. 2006. Kulturlandschaft und Stadt-Wildnis. In Kulturen der Landschaft: Ideen von Kulturlandschaft zwischen Tradition und Modernisierung. Edited by Irene Kazal, Annette Voigt, Angela Weil and Axel Zutz. Landschaftsentwicklung und Umweltforschung 127. Berlin: Technische Universität Berlin, 127 vols, pp. 221-36.

Visscher, Sven De, and Maria Bouverne-De Bie. 2008. Recognizing Urban Public Space as a Co-Educator: Children's Socialization in Ghent. International Journal of Urban and Regional Research 32: 604-16. [CrossRef]

Waterton, Emma. 2013. Landscape and Non-Representational Theories. In The Routledge Companion to Landscape Studies. Edited by Peter Howard, Ian Thompson and Emma Waterton. London/New York: Routledge, pp. 66-75.

Winchester, Hilary P. M., Lily Kong, and Kevin Dunn. 2003. Landscapes: Ways of Imagining the World. London/New York: Routledge.

Wojtkiewicz, Wera. 2015. Sinn-Bild-Landschaft: Landschaftsverständnisse in der Landschaftsplanung: Eine Untersuchung von Idealvorstellungen und Bedeutungszuweisungen. Berlin: Technische Universität Berlin.

Wolf, Mark J. P. 2014. Worlds. In The Routledge Companion to Video Game Studies. Edited by Mark J. P. Wolf and Bernard Perron. New York/London: Routledge Taylor \& Francis Group, pp. 125-31.

Wolf, Mark J. P., and Bernard Perron. 2014. The Routledge Companion to Video Game Studies. New York/London: Routledge Taylor \& Francis Group.

Wylie, John. 2005. A single day's walking: Narrating self and landscape on the South West Coast Path. Transactions of the Institute of British Geographers 30: 234-47. [CrossRef]

Wylie, John. 2007. Landscape. Abingdon: Routledge.

Wylie, John. 2019. Landscape and Phenomenology. In The Routledge Companion to Landscape Studies. Edited by Peter Howard, Ian Thompson, Emma Waterton and Mick Atha. London/New York: Routledge, pp. 127-38.

Zimmermann, Stefan. 2019. Filmlandschaft. In Handbuch Landschaft. Edited by Olaf Kühne, Florian Weber, Karsten Berr and Corinna Jenal. Wiesbaden: Springer VS, pp. 623-29.

Publisher's Note: MDPI stays neutral with regard to jurisdictional claims in published maps and institutional affiliations.

(C) 2020 by the authors. Licensee MDPI, Basel, Switzerland. This article is an open access article distributed under the terms and conditions of the Creative Commons Attribution (CC BY) license (http://creativecommons.org/licenses/by/4.0/). 